\title{
Hyperexpression of CD40 Ligand by B and T Cells in Human Lupus and Its Role in Pathogenic Autoantibody Production
}

\author{
Ami Desai-Mehta, ${ }^{\star \ddagger}$ Liangjun Lu, ${ }^{*}$ Rosalind Ramsey-Goldman, ${ }^{\star}$ and Syamal K. Datta ${ }^{\star \ddagger}$ \\ The Departments of *Medicine and ${ }^{\ddagger}$ Microbiology-Immunology, Northwestern University Medical School, Chicago, Illinois 60611
}

\begin{abstract}
We investigated the role of the costimulatory molecules, CD40 and its ligand CD40L, in the pathogenesis of human SLE. In comparison to normal subjects or patients in remission, PBMC from active lupus patients had a 21-fold increase in the frequency of CD40L-expressing, $\mathrm{CD}^{+} \mathrm{T}$ cells. However, the expression of CD40L induced in either lupus or normal $\mathrm{T}$ cells by mitogenic stimulation could be downregulated equally well by CD40 molecules on autologous B cells. Active lupus patients also had a 22-fold increase in percentage of $\mathrm{CD}^{+} \mathrm{T}$ cells expressing CD40L, consistent with their unusual helper activity in SLE. Surprisingly, patients with active lupus had a 20.5 -fold increase in B cells that spontaneously expressed high levels of CD40L, as strongly as their $\mathrm{T}$ cells. Although lupus patients in remission had low levels of $\mathrm{CD} 40 \mathrm{~L}^{+}$cells in the range of normal subjects, mitogen-induced upregulation of CD40L expression in their $\mathrm{T}$ and $\mathrm{B}$ cells was markedly greater than normal, suggesting an intrinsic defect. A mAb to CD40L blocked significantly the ability of lymphocytes from lupus patients with active and established disease to produce the pathogenic variety of antinuclear autoantibodies in vitro, bolstering the possibility of anti-CD40L immunotherapy for lupus. Future studies on the hyperexpression of CD40L could elucidate a regulatory defect in the pathogenic $\mathrm{T}$ and B cells of lupus. (J. Clin. Invest. 1996. 97:2063-2073.) Key words: system lupus erythematosus - anti-DNA autoantibodies $\bullet$ autoimmune disease $\cdot$ CD40 ligand expression $\bullet$ immunotherapy
\end{abstract}

\section{Introduction}

Production of the pathogenic variety of antinuclear autoantibodies in SLE (1-10), is driven by certain T helper (Th) $)^{1}$ cells that are prevalent in patients with active lupus nephritis but not in normal subjects or patients in remission (11-15). We were able to clone these Th cells in vitro by selecting for their

Address correspondence to Dr. Syamal K. Datta, Arthritis Division, Ward 3-315, Northwestern University Medical School, 303 East Chicago Avenue, Chicago, IL 60611-3008. Phone: 312-503-8003; FAX: 312-503-0994.

Received for publication 15 November 1995 and accepted in revised form 14 February 1996.

1. Abbreviations used in this paper: dsDNA, double-stranded DNA; EBV-BCL, EBV-transformed B cell line; NK, natural killer; PE, phycoerythrin; SAC, Staphylococcus aureus Cowan I strain; ssDNA, single-stranded DNA; Th, T helper cell.

J. Clin. Invest.

(C) The American Society for Clinical Investigation, Inc.

0021-9738/96/05/2063/11 \$2.00

Volume 97, Number 9, May 1996, 2063-2073 special functional property $(13,14)$. Among 396 "autoreactive" $\mathrm{T}$ cell clones derived from five patients with lupus nephritis, only $59(\sim 15 \%)$ had the ability to selectively augment the production of pathogenic anti-DNA autoantibodies when cultured with autologous B cells (14). Therefore, the pathogenic autoantibody-inducing Th cells of lupus are a special group of autoimmune $\mathrm{T}$ cells that are distinct from conventional autoreactive $\mathrm{T}$ cells. Analogous results were obtained in lupus mice (11, 12, 16-20) and similar pathogenic autoantibody-inducing Th clones could rapidly induce lupus nephritis when transferred in vivo into preautoimmune mice (16). Although the contribution of certain double negative $\left(\mathrm{CD} 4^{-} / \mathrm{CD}^{-}\right)$and $\mathrm{CD}^{+}$Th cells are important, $\mathrm{CD}^{+} \mathrm{Th}$ cells are the prime movers of the pathogenic autoimmune response in SLE (13, 14, 21). The initial findings showing that the antigen binding CDR3 loops of $\mathrm{T}$ cell receptors expressed by these special Th cells of lupus contain a recurrent motif of charged residues led to the identification of the autoantigens that activate them: charged DNA-binding proteins in nucleosomes, namely $\mathrm{HMG}$ and histones, presented by MHC class II molecules (15-18). The pathogenic autoantibody-producing B cells of lupus bind DNA complexed with these charged nuclear proteins $(2,9,15$, $16,18)$. Most probably these B cells then process and present the nucleosomal proteins to the pathogenic $\mathrm{T}$ cells which in turn drive the $\mathrm{B}$ cells to make pathogenic autoantibodies (14$16,18)$. This cognate Th and B cell interaction is not only essential for the production of pathogenic anti-DNA autoantibodies in SLE (12-14) but other types of autoantibodies as well (22-25). On the other hand, several studies $(26,27)$ have indicated that an intrinsic B cell hyperactivity that is manifest in lupus from early life $(28,29)$ is sufficient by itself to cause disease without the help of T cells.

Nevertheless, it is also widely believed that during cognate contact-dependent help for antibody production, the CD40 ligand (CD40L or gp39) is transiently expressed on activated $\mathrm{CD}^{+}{ }^{+}$Th cells, and it binds to CD40 on the antigen-specific B cells transducing a second, costimulatory signal. This signal is essential for B cell growth and differentiation and for the generation of memory $\mathrm{B}$ cells by preventing apoptosis of germinal center B cells that have encountered antigen (30-42). Therefore, in this study we addressed the following questions: (a) Is the interaction between CD40 and its ligand, CD40L, important for the production of pathogenic autoantibodies in human lupus? (b) Is the expression of CD40L and its regulation defective in human lupus T cells? $(c)$ Are human lupus B cells still dependent on CD40 transduced signals or are they autonomous? Surprisingly, we found that hyperexpression of CD40L occurs not only in the $\mathrm{T}$ cells but also in the B cells of lupus patients.

\section{Methods}

Patients and healthy donors. Eight patients with active lupus (seven females and one male; aged 18-50 yr), seven patients in long-term remission (all females; aged 21-51 yr) and six normal (healthy) subjects 
(five females and one male; aged 22-40 yr) were studied. Disease activity by Systemic Lupus Activity Measure or SLAM (43), ranged between 7 and 20 for active patients, except for one patient who mainly had severe thrombocytopenia. None of the patients in remission had detectable proteinuria or serum anti-DNA autoantibodies at the time of testing and their SLAM ranged between 0 and 4 . The patients in remission had never received any cytotoxic drugs, and they were not receiving any steroids at the time their blood samples were drawn for the assays. Steroids had been discontinued for several years in the remission patients, except for two patients who had received a short course of low dose steroids (Prednisone, $10 \mathrm{mg} / \mathrm{d}$ ) 2 mo before the assays.

Antibodies. Anti-CD3 (OKT3) and anti-CD40 (G28-5) mAb secreting hybridomas were obtained from American Type Culture Collection (Rockville, MD). The hybridoma supernatants were concentrated by $47 \%$ saturated ammonium sulfate precipitation and dialysis before use. Anti-CD28 antibody (mAb 9.3) containing ascites was kindly provided by Kathy Cabrian (Bristol-Myers Squibb, Seattle, WA). Purified mAb to human CD40L (clone 24-31), anti-human CD40L FITC, as well as isotype matched control IgG1 antibody and control IgG1 FITC were obtained from Ancell (Bayport, MN). Phycoerythrin (PE)-conjugated $\mathrm{mAbs}$ to human $\mathrm{CD} 4, \mathrm{CD} 8, \mathrm{CD} 20$, and CD16, control PE-mAb, FITC-conjugated $\mathrm{mAb}$ to CD3 and CD69 were purchased from Becton Dickinson \& Co. (San Jose, CA). For flow cytometry, all mAbs were used at optimal saturating concentrations as recommended by the manufacturers.

Cell preparations and short-term T cell lines. Peripheral blood mononuclear cells (PBMC) were obtained from lupus patients and healthy donor by centrifugation of heparinized blood over Ficoll-Hypaque (Pharmacia LKB Biotechnology Inc., Piscataway, NJ) gradient (13). $\mathrm{CD}^{+}$cells were selected from PBMCs using anti-CD4 mAb-coupled magnetic beads (Dynal Inc., Oslo, Norway) and rested overnight to detach from beads. $\mathrm{CD}^{+}$short-term $\mathrm{T}$ cell lines were made within $10-14 \mathrm{~d}$ after one round of stimulation of the $\mathrm{CD} 4^{+} \mathrm{T}$ cells with platebound anti-CD3 and anti-CD28 mAb and rIL-2 $(20 \mathrm{U} / \mathrm{ml})$.

Stimulation of $T$ and $B$ cells in PBMCs ex vivo. PBMCs (1.5-2.0 $\left.\times 10^{6} / \mathrm{ml}\right)$ were cultured for $18 \mathrm{~h}$ at $37^{\circ} \mathrm{C}$ with anti-CD3 mAb $(1 / 625$ dilution of SAS cut supernatant, unless specified otherwise) coated onto culture wells to stimulate $\mathrm{T}$ cells in vitro. Other aliquots of the PBMCs were cultured for $18 \mathrm{~h}$ at $37^{\circ} \mathrm{C}$ with Staphylococcus aureus Cowan I strain (SAC) at 1/30,000 (Pansorbin, Calbiochem Corp., La Jolla, CA) and $20 \mathrm{U} / \mathrm{ml}$ of rIL-2 to stimulate B cells in vitro (44). Cells were harvested and stained for flow cytometry.

Flow cytometry analysis. Unstimulated and stimulated cells were harvested and stained as described (13). Briefly, the cells were washed in $\mathrm{FACS}^{\circledR}$ buffer containing $\mathrm{PBS} / 5 \% \mathrm{FCS} / 0.05 \%$ sodium azide and incubated with $10 \mu \mathrm{g}$ of human IgG (Sigma Chemical Co., St. Louis, MO) for $30 \mathrm{~min}$ at $4^{\circ} \mathrm{C}$ to block $\mathrm{Fc}$ receptors. Cells were washed to remove excess $\mathrm{IgG}$ and were double-stained with either FITC-conjugated mAb against human $\mathrm{CD} 40 \mathrm{~L}$ or FITC-control IgG $\mathrm{mAb}$ and $\mathrm{PE}$-conjugated $\mathrm{mAb}$ against $\mathrm{CD} 4$ or $\mathrm{CD} 8$ or $\mathrm{CD} 20$ or $\mathrm{CD} 16$, or PE-control IgG $\mathrm{mAb}$ for $30 \mathrm{~min}$ at $4^{\circ} \mathrm{C}$. Cells were washed twice, resuspended in $\mathrm{FACS}^{\circledR}$ buffer, fixed with $1 \%$ paraformaldehyde, and analyzed by flow cytometry using Becton Dickinson FACScan. PBMCs were gated according to their forward and side scatter characteristics. Different subsets of cells $\left(\mathrm{CD} 4^{+}, \mathrm{CD} 8^{+}, \mathrm{CD} 20^{+}\right)$were gated further based on FL2 staining. The samples were analyzed using Cellquest software (Becton Dickinson).

Regulation of $C D 40 L$ expression in $\mathrm{CD}^{+}$short-term $\mathrm{T}$ cell lines. $\mathrm{CD}^{+} \mathrm{T}$ cell lines were rested for $7-10 \mathrm{~d}$ in medium without rIL-2. The T cells $\left(1 \times 10^{6} / \mathrm{ml}\right)$ were then stimulated in complete RPMI medium (13-15) with either anti-CD3 (1/125 dilution) coated on the culture wells or with $5 \mathrm{ng} / \mathrm{ml}$ PMA (Sigma Chemical Co.) and $0.5 \mu \mathrm{g} / \mathrm{ml}$ ionomycin (Sigma) for $6 \mathrm{~h}$ at $37^{\circ} \mathrm{C}$. After the $6 \mathrm{~h}$ stimulation, in some cases, an equal number $\left(1 \times 10^{6} / \mathrm{ml}\right)$ of autologous EBV-transformed $\mathrm{B}$ cell line (EBV-BCL) were added to the activated $\mathrm{CD}^{+}{ }^{+} \mathrm{T}$ cells and incubated for an additional $2 \mathrm{~h}$ at $37^{\circ} \mathrm{C}$ according to described protocols (45-47). The EBV-BCL were pretreated with either $10 \mu \mathrm{g} / \mathrm{ml}$ of anti-CD40 or control $\mathrm{mAb}$ for $10 \mathrm{~min}$ before addition to the activated
$\mathrm{T}$ cells. The cells were harvested after incubation and double stained to detect $\mathrm{CD} 40 \mathrm{~L}$ or $\mathrm{CD} 69$ expression on $\mathrm{CD}^{+}{ }^{+} \mathrm{T}$ cells. Separate aliquots of $\mathrm{T}$ cells from the lines were incubated by themselves after PMA/ionomycin stimulation without coculturing with EBV-BCL and harvested at different time points to determine the percentage of $\mathrm{CD}^{+}{ }^{+} \mathrm{T}$ cells that expressed CD40L by flow cytometry.

Helper assays for IgG autoantibody production. PBMCs $\left(0.3 \times 10^{6}\right.$ cells in $200 \mu \mathrm{l} /$ microwell) were cultured in the presence of either antiCD40L mAb $(10 \mu \mathrm{g} / \mathrm{ml})$ or isotype matched control IgG1 $(10 \mu \mathrm{g} / \mathrm{ml})$ in complete RPMI with $10 \%$ FCS for $13 \mathrm{~d}$ at $37^{\circ} \mathrm{C}(13,14)$. Baseline production of autoantibodies secreted by lupus $\mathrm{B}$ cells was measured by culturing enriched $\mathrm{B}$ cells alone $\left(0.1 \times 10^{6}\right.$ cells/microwell $)$. These $\mathrm{B}$ cells were obtained after depletion of $\mathrm{CD}^{+}$and $\mathrm{CD} 8^{+} \mathrm{T}$ cells from PBMCs, using anti-CD4 and anti-CD8 mAb coupled magnetic beads (Dynal). To exclude autoantibodies produced by B cells that were already preactivated in vivo, $120 \mu \mathrm{l}$ of medium from each culture was replaced with fresh medium and corresponding $\mathrm{mAb}$ on day 5 without disturbing the cells at the bottom of the microwells (13). At the end of $13 \mathrm{~d}$, production of IgG autoantibodies to single-stranded (ss) DNA, double-stranded (ds) DNA, and nucleosomes (histone/DNA complex), as well as total polyclonal IgG was quantitated in the culture supernatants.

ELISA. IgG class autoantibodies to ssDNA, dsDNA, and nucleosomes (histone/DNA complexes) as well as total polyclonal IgG were measured as described $(13,18,48)$. Standard curves for antiDNA ELISA were obtained by serial dilutions of one lupus patient's serum that had high anti-DNA and antinucleosome autoantibody titer. All sera were heat inactivated at $56^{\circ} \mathrm{C}$ for $30 \mathrm{~min}$ before use. The absorbance value (at $405 \mathrm{~nm}$ ) of 1/1000 dilution of the reference patient's serum was considered to be equivalent to $1 \mathrm{U} / \mathrm{ml}$ of antissDNA, anti-dsDNA or antinucleosome autoantibodies, and the standard curve with the same reference serum was generated with each assay. Purified human IgG (Organon Teknika-Cappel, West Chester, PA) was used to obtain standard curves for total polyclonal IgG ELISA.

$B$ cell purification and semiquantitative reverse transcriptase $(R T)$ $P C R$ for CD40L expression. B cells were positively selected and isolated from PBMC using magnetic beads coated with mAb to CD19 (Dynal) according to the manufacturer. After detachment of the beads, cell purity was analyzed by flow cytometry by staining B cells with anti-CD20 mAb conjugated to PE: $99.7 \%$ of the purified cells were B cells with $<0.2 \%$ being $\mathrm{CD}^{+}$cells.

Total RNA was extracted from enriched B cells or from T cells from the short-term lines (described above) using TRIzol (Life Technologies Inc., Gaithersburg, MD) according to the manufacturer's instructions. Reverse transcription was performed with $0.8 \mu \mathrm{g}$ of RNA, $2.5 \mu \mathrm{M}$ Random Hexamers, $1 \mathrm{mM}$ dNTP, $3.5 \mu \mathrm{M} \mathrm{MgC1}{ }_{2}, 20 \mathrm{U}$ RNase inhibitor, and $50 \mathrm{U}$ murine leukemia virus reverse transcriptase in $20 \mu \mathrm{l} 1 \times$ PCR buffer. The mixture was incubated at room temperature for $30 \mathrm{~min}$, followed by $42^{\circ} \mathrm{C}$ for $30 \mathrm{~min}, 99^{\circ} \mathrm{C}$ for $5 \mathrm{~min}$, and $5^{\circ} \mathrm{C}$ for $5 \mathrm{~min}$. All reagents used in the cDNA synthesis and PCR were from GeneAmp RNA PCR kit (Perkin Elmer, Branchburg, NJ).

The protocol for amplifying CD40L message was as described previously $(15,17,44)$ with slight modifications: after reverse transcription, $2.5 \mathrm{U}$ Taq DNA polymerase, $3.75 \mu \mathrm{M} \mathrm{MgCl}_{2}$, and $150 \mathrm{nM}$ of each primer in $80 \mu \mathrm{l} 1 \times$ PCR buffer were added to the cDNA mixture. After denaturation at $94^{\circ} \mathrm{C}$ for $5 \mathrm{~min}, 45$ cycles of amplification were performed at $95^{\circ} \mathrm{C}$ for $1 \mathrm{~min}, 54^{\circ} \mathrm{C}$ for $1.5 \mathrm{~min}$, and $72^{\circ} \mathrm{C}$ for 2.5 min per cycle. The primers for $\mathrm{CD} 40 \mathrm{~L}$ message amplification were $5^{\prime}$ ACATACAACCAAACTTCTCCC-3' (sense) and 5'-AGATGTTGTTTTACTGCTGGC-3' (antisense). In some cases a second step PCR was performed to further amplify $1 \mu l$ of the first PCR product with $2.5 \mathrm{U}$ Taq DNA polymerase, $150 \mathrm{nM}$ of each primer, and $0.2 \mathrm{mM}$ dNTP in $100 \mu \mathrm{l} 1 \times$ PCR buffer with $3.75 \mu \mathrm{M} \mathrm{MgCl}_{2}$. The first PCR-product DNA was denatured at $94^{\circ} \mathrm{C}$ for $5 \mathrm{~min}$ and amplified for 30 cycles, each at $95^{\circ} \mathrm{C}$ for $1 \mathrm{~min}, 54^{\circ} \mathrm{C}$ for $1 \mathrm{~min}$, and $72^{\circ} \mathrm{C}$ for 2 min. As an internal control for each PCR, HLA-DQ $\alpha$ chain message, which is constitutively expressed by human $\mathrm{B}$ and $\mathrm{T}$ cells, was also 
amplified by RT-PCR under identical conditions except the primers were as follows: (GH26) 5'-GTGCTGCAGGTGTAAACTTGTACCAG-3', and (GH27) 5'-CACGGATCCGGTAGCAGCGGTAGAGTTG-3' (49).

\section{Results}

Hyperexpression of CD40L by $T$ and B cells of human lupus. PBMCs from patients with active lupus or patients in remission or normal subjects were analyzed by two-color staining and flow cytometry for CD40L expression (Table I and Figs. 1-3). In comparison to normal subjects, PBMC from patients with active lupus had on the average a 21 -fold increase in the percentage of CD40L-expressing, CD ${ }^{+} \mathrm{T}$ cells $(P<0.0005$, two-tailed $t$ test). On further stimulation of the PBMC with anti-CD3, the percentage of CD40L-expressing CD4 ${ }^{+} \mathrm{T}$ cells increased fivefold in normal but only 1.4-fold in active lupus. However, the frequency of $\mathrm{CD} 40 \mathrm{~L}^{+} / \mathrm{CD} 4^{+} \mathrm{T}$ cells still remained markedly higher in active lupus $(P<0.001)$ than in normal PBMC after stimulation (Table I, Fig. 1). The antiCD3 antibody was titrated and used at a submaximal stimulating dose (1:625 dilution) to bring out the differences in threshold of stimulation between lupus and normal $\mathrm{T}$ cells. In lupus patients in remission of their disease, the percentage of $\mathrm{CD}_{40 \mathrm{~L}^{+}} \mathrm{CD}^{+} \mathrm{T}$ cells in freshly isolated PBMC was not significantly different from normal PBMC. However, on anti-CD3 stimulation the $\mathrm{CD}_{40 \mathrm{~L}^{+}} \mathrm{CD}^{+}{ }^{+} \mathrm{T}$ cells increased 13-fold in the inactive lupus patients and were significantly higher than in anti-CD3 stimulated PBMC of normal subjects $(P<0.01)$. Indeed, in contrast to the marked difference between unstimulated PBMC from active vs. remission patients $(P<0.001)$, the anti-CD3-stimulated PBMC of remission patients had a frequency of $\mathrm{CD} 40 \mathrm{~L}^{+} \mathrm{CD} 4^{+} \mathrm{T}$ cells comparable to that from active lupus $(P>0.05)$.

Similarly, the frequency of $\mathrm{CD}^{+} \mathrm{T}$ cells that expressed CD40L in freshly isolated PBMC from active lupus patients (Fig. 2) was on the average $\sim 22$-fold higher than in normal subjects $(P<0.005)$ and 16 -fold higher than in PBMC from patients in remission $(P<0.01)$. On anti-CD3 stimulation, the levels of $\mathrm{CD}^{4} 0 \mathrm{~L}^{+} \mathrm{CD}^{+} \mathrm{T}$ cells in PBMC of active lupus still remained markedly higher than in anti-CD3 stimulated, normal $(P<0.001)$, or remission patient's $(P<0.01)$ PBMC (Table I, Fig 2). Although the unstimulated $\mathrm{CD}^{+} \mathrm{T}$ cells from normal subjects and patients in remission expressed comparable levels of CD40L $(P>0.1)$, on anti-CD3 stimulation the re- mission patient's CD8 ${ }^{+} \mathrm{T}$ cells increased CD40L expression by 11 -fold as compared to a 3.6-fold increase in normal PBMC $(P<0.05)$.

None of the patients in remission were receiving any cytotoxic drugs or steroids at the time of these assays. The percentage of $\mathrm{CD}^{+} \mathrm{T}$ cells that were $\mathrm{CD} 69^{+}$in the unstimulated PBMC from the remission patients was $0.52 \pm 0.22$ (mean \pm SEM), and on anti-CD3 stimulation the percentage increased to $27.90 \pm 5.40$. The corresponding values from the remission patients for $\mathrm{CD}^{+} \mathrm{T}$ cells that were $\mathrm{CD}^{+}$were $1.97 \pm 0.43$ (unstimulated) and 27.50 \pm 6.35 (anti-CD3 stimulated). These values were similar to those in normal subjects (see later in Table III, reference 46, and data not shown).

Remarkably, even without any stimulation in vitro, the B cells from patients with active lupus (Table I, Fig. 3) also had a marked increase in CD40L expression: 20.5 -fold over that in normal subjects $(P<0.0005)$ and 12.3 -fold over that in patients in remission $(P<0.0005)$. The levels of $\mathrm{CD} 40 \mathrm{~L}^{+} \mathrm{B}$ cells in unstimulated PBMC were comparable in normal subjects and patients in remission $(P>0.1)$. Upon stimulation with SAC and IL-2, the frequency of CD $40 \mathrm{~L}^{+} \mathrm{B}$ cells was still significantly higher in active lupus PBMC as compared to normal $(P<0.01)$, although the increase from unstimulated levels in the case of active lupus was 2.5 -fold vs. a 7.6-fold increase in normal PBMC (Table I, Fig. 3). However, on stimulation the levels of $\mathrm{CD}_{40 \mathrm{~L}^{+}} \mathrm{B}$ cells increased 17-fold in PBMC from patients in remission bringing them to levels comparable to active lupus PBMC $(P>0.1)$ but markedly higher than in stimulated normal PBMC $(P<0.01)$. The mean fluorescence intensities of CD40L expression by the $\mathrm{CD} 4^{+} \mathrm{T}$ cells and $\mathrm{CD}^{+} \mathrm{T}$ cells and the $\mathrm{B}$ cells of active lupus patients were comparable with mean \pm SEM values of $64.11 \pm 5.16,72.30 \pm 8.76$, and $67.39 \pm 4.73$ respectively (Figs. 1-4). Acid wash of the B cells by incubating with PBS at pH 4.1 for 3 min, as described previously (44), did not decrease CD40L staining (data not shown).

Although the lupus patients had lymphocytopenia as compared to normal subjects, they still had significant increases in the absolute numbers of $\mathrm{CD}_{40 \mathrm{~L}^{+}} \mathrm{T}$ and $\mathrm{B}$ cells (Table II), similar to the increases seen when the $\mathrm{CD}_{40 \mathrm{~L}^{+}}$cells were expressed as percent values (Table I).

To establish further that CD40L expressed by B cells is not passively acquired from activated T cells, PCR amplifications of CD40L mRNA from highly purified $\mathrm{B}$ cells were done. $\mathrm{B}$ cells from a normal subject expressed CD40L only on stimula-

Table I. Hyperexpression of CD40L by Lupus T and B Cells

\begin{tabular}{|c|c|c|c|c|c|c|}
\hline \multirow[b]{3}{*}{ Subjects } & \multicolumn{6}{|c|}{ Percentage of cells expressing CD $40 \mathrm{~L}$ among:* } \\
\hline & \multicolumn{2}{|c|}{$\mathrm{CD}^{+} \mathrm{T}$ cells } & \multicolumn{2}{|c|}{$\mathrm{CD} 8^{+} \mathrm{T}$ cells } & \multicolumn{2}{|c|}{$\mathrm{B}$ cells $\left(\mathrm{CD} 20^{+}\right)$} \\
\hline & unstim. & anti-CD3 & unstim. & anti-CD3 & unstim. & $\mathrm{SAC}+\mathrm{IL}-2$ \\
\hline & \multicolumn{6}{|c|}{ Mean $\pm S E M$} \\
\hline Normal & $0.83 \pm 0.14$ & $4.22 \pm 1.32$ & $0.98 \pm 0.31$ & $3.58 \pm 2.18$ & $0.56 \pm 0.08$ & $4.26 \pm 1.04$ \\
\hline Active lupus & $17.27 \pm 2.03$ & $23.40 \pm 2.95$ & $21.17 \pm 4.01$ & $35.35 \pm 3.32$ & $11.47 \pm 0.96$ & $28.12 \pm 5.91$ \\
\hline Remission & $1.16 \pm 0.29$ & $14.97 \pm 2.86$ & $1.32 \pm 0.53$ & $14.81 \pm 3.62$ & $0.93 \pm 0.14$ & $15.88 \pm 2.60$ \\
\hline
\end{tabular}

* Results obtained by flow cytometry of PBMC that were stained (two color) with mAb to CD4 and CD40L, or CD8 and CD40L, or CD20 and CD40L. The PBMC were stained either as unstimulated cells ex vivo (unstim.) or after stimulation with anti-CD3 mAb (anti-CD3) or with SAC + IL-2. Background values of staining by appropriate control mAbs were subtracted. 
NORMAL

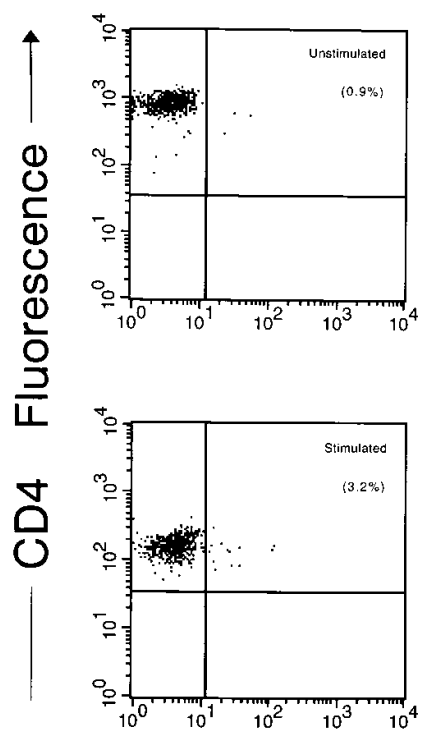

REMISSION
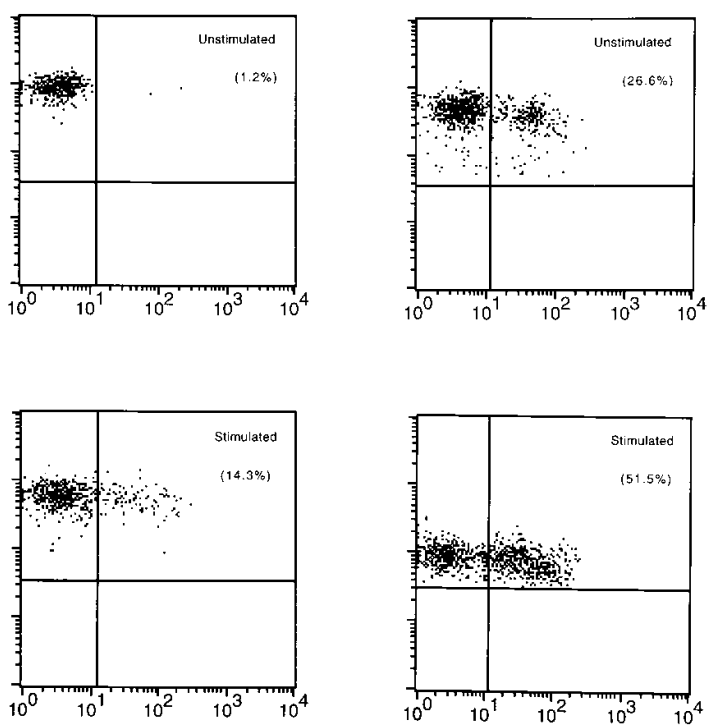

CD40L Fluorescence
ACTIVE

Figure 1. Two color immunofluorescence (dot plots) of "gated" $\mathrm{CD} 4{ }^{+} \mathrm{T}$ cells for CD40L expression. Examples from analysis of PBMC from normal subjects and lupus patients in remission or with active disease are shown. Based on background staining (not shown), the dot-plots were divided into four quadrants. Cells staining with both mAbs are in the right upper quadrant of each dot plot with percent positive cells indicated in parenthesis. Upper panels show results with unstimulated cells, and lower panels show that with antiCD3-stimulated cells. tion by SAC and IL-2 but not by anti-CD3 stimulation, indicating that $\mathrm{CD} 40 \mathrm{~L}$ message was endogenously upregulated in $\mathrm{B}$ cells and was not due to any contaminating T cells (Fig. 5). The presence of CD40L mRNA could be detected in normal B cells only after SAC + IL-2 stimulation, and only then after a second PCR amplification (30 additional cycles). In contrast, CD40L message was detectable in purified B cells from patients with active lupus, without any stimulation ex vivo, and after only one round of PCR, consistent with the hyperexpression seen by flow cytometry (Figs. 3-5, Tables I and II).

Two color staining of PBMC from lupus patients for natural killer (NK) cells with anti-CD16 and anti-CD40L mAb did not show any CD40L-expressing NK cells (data not shown).

Regulation of CD40L expression in Lupus T cells. On mitogenic activation of normal human T cells, CD40L expression peaks by $6-8 \mathrm{~h}$ and then goes down by $40 \mathrm{~h}(45-47,50)$. Even
NORMAL

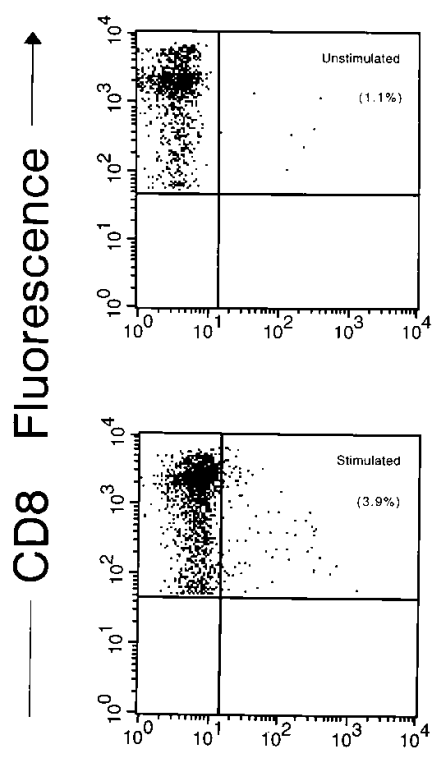

\section{REMISSION}
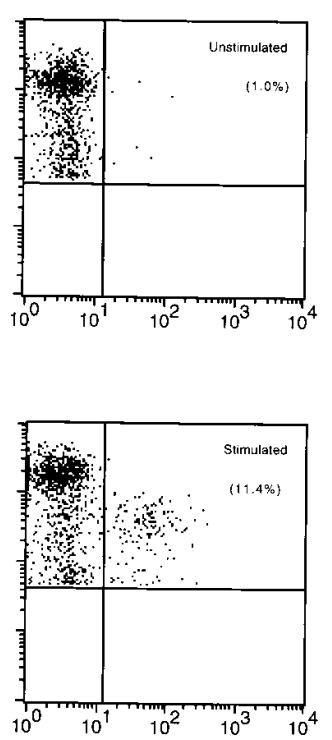

\section{ACTIVE}
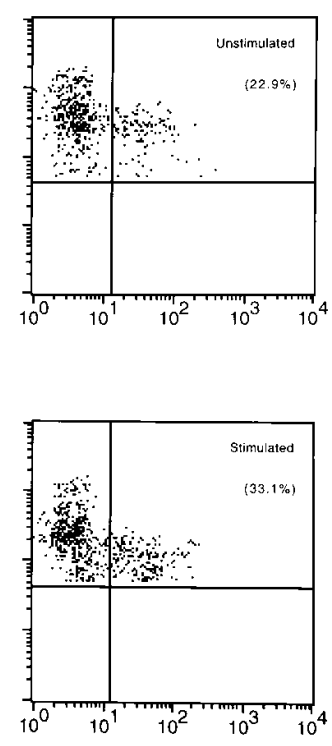

Fluorescence
Figure 2. Examples of two color immunofluorescence of $\mathrm{CD}^{+} \mathrm{T}$ cells expressing CD40L. The other features of this Figure are the same as in Fig. 1 
NORMAL
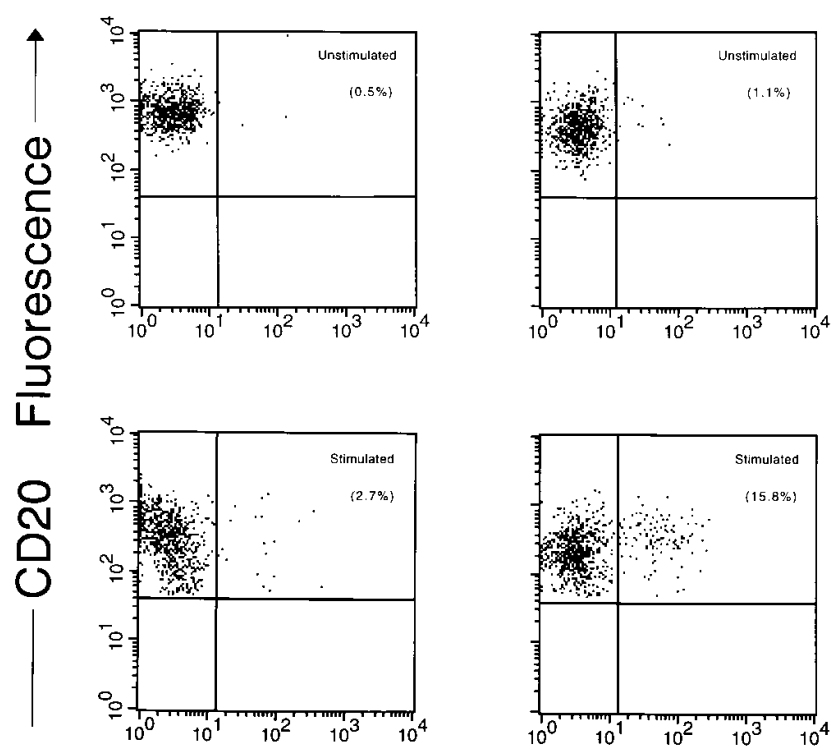

CD40L Fluorescence

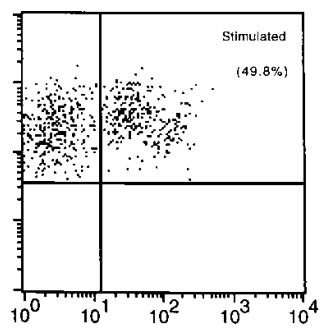

ACTIVE

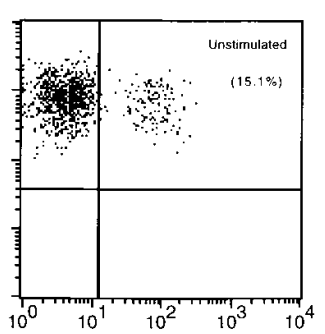

Figure 3. Examples of two color immunofluorescence of $\mathrm{CD} 20^{+} \mathrm{B}$ cells expressing CD40L. The other features are the same as in Fig. 1 legend, except for the lower panels where the cells were stimulated with SAC and without addition of any mitogen in vitro, the levels of CD40L $\mathrm{L}^{+}$ $\mathrm{T}$ and $\mathrm{B}$ cells in the PBMC mixture of active lupus patients remained high even after $40 \mathrm{~h}$ of culture (data not shown). This result suggested either an intrinsic defect or perpetual rounds of stimulation due to interactions between CD40L and CD40 molecules expressed by $\mathrm{T}$ and $\mathrm{B}$, and $\mathrm{B}$ and $\mathrm{B}$ cells in the cultured PBMC of lupus. To study the T cells in isolation, we derived short-term (2-wk old) $\mathrm{CD}^{+}{ }^{+} \mathrm{T}$ cell lines from six patients with active lupus and three normal subjects by just one round of anti-CD3 and anti-CD28 stimulation of their CD4-enriched T cells. CD40 expressed by B cells is known to rapidly downmodulate CD40L, but not CD69 expression by activated T cells from normal subjects (45-47). Therefore, we also derived EBV-BCL that constitutively express CD40 (45-47) from the same subjects from which the short-term $\mathrm{T}$ cell lines were derived. After resting the $\mathrm{T}$ cell lines for $7-10 \mathrm{~d}$, the unstimulated $\mathrm{T}$ cells from active lupus patients tended to have higher levels of CD40L-expressing CD $4^{+} \mathrm{T}$ cells than those from the normal

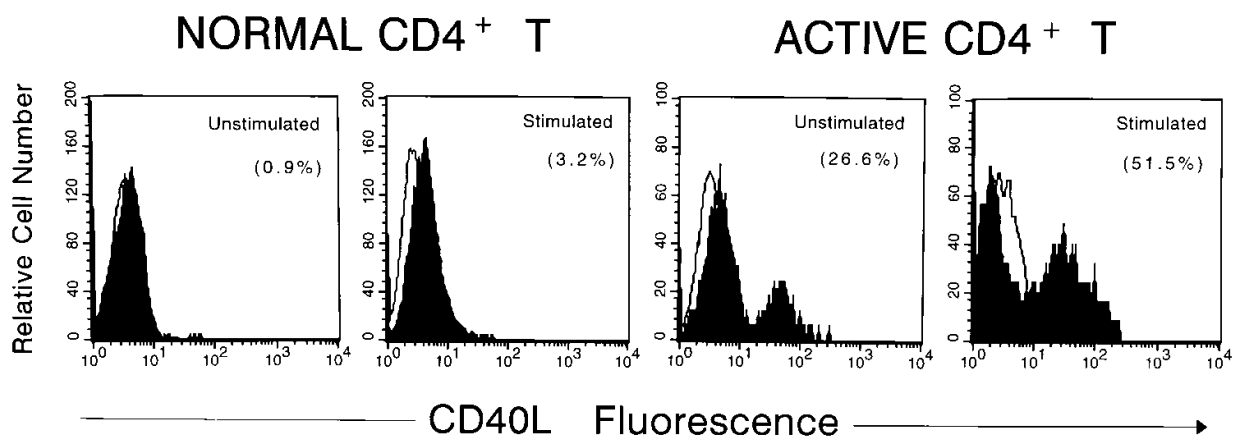

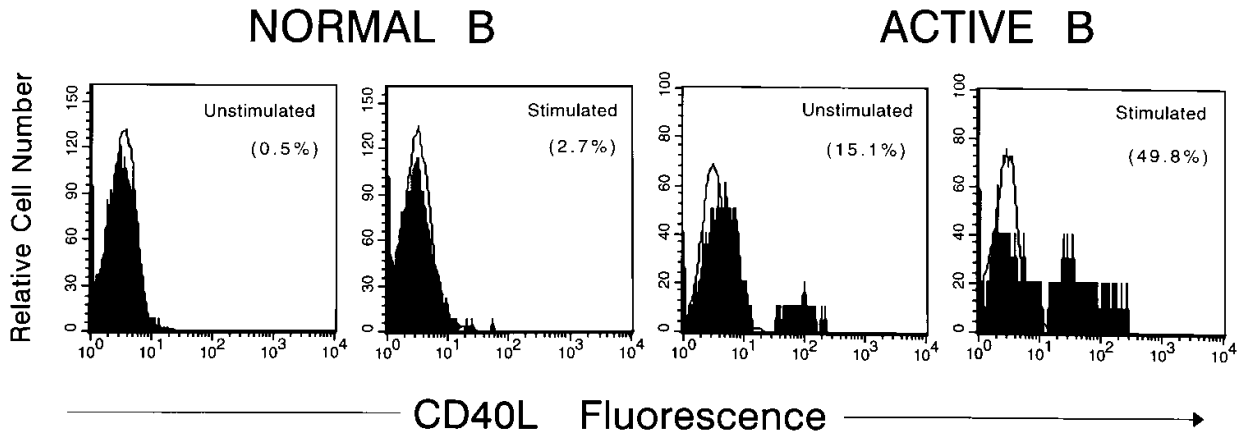

Figure 4. Histograms showing the hyperexpression of CD40L (solid black) by gated $\mathrm{CD} 4^{+} \mathrm{T}$ cells and $\mathrm{B}$ cells $\left(\mathrm{CD} 20^{+}\right)$of patients with active lupus (active) as compared to those from normal subjects. Percentage $\mathrm{CD} 40 \mathrm{~L}^{+}$ cells are indicated in parentheses. These examples correspond to the dot plots shown in Figs. 1 and 3, but the histograms show the comparable intensities of CD40L hyperexpression in the $\mathrm{T}$ and $\mathrm{B}$ cells of lupus better. 


\begin{tabular}{|c|c|c|c|c|c|c|}
\hline \multirow[b]{3}{*}{ Subjects } & \multicolumn{6}{|c|}{ Numbers of CD40L expressing cells among:* } \\
\hline & \multicolumn{2}{|c|}{$\mathrm{CD} 4^{+} \mathrm{T}$ cells } & \multicolumn{2}{|c|}{$\mathrm{CD} 8^{+} \mathrm{T}$ cells } & \multicolumn{2}{|c|}{$\mathrm{B}$ cells $\left(\mathrm{CD} 20^{+}\right)$} \\
\hline & unstim. & anti-CD3 & unstim. & anti-CD3 & unstim. & $\mathrm{SAC}+\mathrm{IL}-2$ \\
\hline & \multicolumn{6}{|c|}{ Mean $\pm S E M$} \\
\hline Normal & $6.04 \pm 0.80$ & $28.05 \pm 7.40$ & $4.98 \pm 1.25$ & $15.35 \pm 9.13$ & $1.23 \pm 0.21$ & $10.48 \pm 1.84$ \\
\hline Active lupus & $29.19 \pm 7.53$ & $43.39 \pm 12.11$ & $52.45 \pm 9.53$ & $69.51 \pm 11.39$ & $21.38 \pm 5.23$ & $58.81 \pm 12.89$ \\
\hline Remission & $3.93 \pm 1.20$ & $50.57 \pm 10.36$ & $1.63 \pm 0.74$ & $30.53 \pm 13.05$ & $3.76 \pm 1.93$ & $56.97 \pm 23.71$ \\
\hline
\end{tabular}

*Results show the yield of CD40L $\mathrm{L}^{+}$cells in PBMC obtained from $1 \mathrm{~mm}^{3}$ of peripheral blood, either as unstimulated PBMC ex vivo (unstim.) or after stimulation overnight with anti-CD3 mAb or with SAC + IL-2. The number of CD40L ${ }^{+}$cells in each subject was calculated by using the total PBMC count obtained immediatedly after purification from blood and the percent values of cells in each subset obtained by flow cytometry of the subject's PMBC (Table I and data not shown). In unstimulated PBMC, the total number (mean \pm SEM per $\mathrm{mm}^{3}$ of peripheral blood) of CD $4^{+} \mathrm{T}$ cells in normal subjects was $647.30 \pm 49.41$, in patients with active lupus it was $197.76 \pm 65.48$, and in remission patients it was $355.12 \pm 60.78$. The corresponding values for $\mathrm{CD}^{+} \mathrm{T}$ cells were respectively, 418.33 $\pm 76.38,210.38 \pm 12.84$, and $192.16 \pm 37.22$; and those for B $\left(\mathrm{CD} 20^{+}\right)$cells were respectively, 218.25 \pm 7.17 , 188.68 \pm 41.49 , and 353.68 \pm 132.50 . The percentage of $\mathrm{CD} 40 \mathrm{~L}^{+} \mathrm{T}$ and $\mathrm{B}$ cells can be recalculated from the data in this Table and they are concordant with, but are not identical to, the values obtained directly from flow cytometry in Table I. The minor differences are probably due to loss of cells during processing of the PBMC for flow cytometry after the initial Ficoll-Hypaque purification and cell count.

T cell lines (Table III). Upon PMA + ionomycin stimulation for $6 \mathrm{~h}$, both types of lines were maximally stimulated for expression of CD40L, and parallel staining for another T-cell activation marker with anti-CD69 supported this result. The upregulation of CD40L in the $\mathrm{CD} 4^{+} \mathrm{T}$ cells in both types of $\mathrm{T}$ cell lines could be markedly downmodulated by incubation with autologous EBV-BCL for $2 \mathrm{~h}$ (Table III, Fig. 6). Preincubation of the EBV-BCL with anti-CD40 mAb could block the downmodulatory effect indicating that CD40 molecules on the EBV-BCL were responsible (Table III, Fig. 6). Similar results were obtained when anti-CD3 antibody was used at a submaximal dose to stimulate the T cell lines. CD40 molecules on autologous EBV-BCL downmodulated CD40L expression by the anti-CD3 activated $\mathrm{T}$ cells in both types of lines, even below their "resting" (unstimulated) levels. Interestingly, antiCD3 stimulation induced a much higher level of CD40Lexpressing $\mathrm{T}$ cells in the lupus $\mathrm{T}$ cell lines than the normal $\mathrm{T}$ cell lines, but their levels of CD69 expression were comparable (Table III). These results are similar to those obtained with freshly isolated PBMC (Tables I and II).

The kinetics of expression of CD40L by activated CD4 ${ }^{+} \mathrm{T}$ cells from lupus and normal subjects were also similar when $\mathrm{T}$ cells from respective lines were cultured by themselves after PMA + ionomycin stimulation, without the addition of any EBV-BCL (Fig. 7).
Anti-CD40L inhibits the production of the pathogenic variety of autoantibodies by lupus patient's lymphocytes. Previous work showed that the production of pathogenic autoantibodies, such as the clonally restricted and predominantly cationic IgG autoantibodies to ssDNA, dsDNA, and nucleosomes by B cells in vitro, requires $\mathrm{T}$ cell help $(13-15,18)$ and is detectable only in PBMC from patients with active lupus (13). The results from six of the patients with active lupus B and T cells were cultured together as unfractionated PBMC vs. when the B cells were cultured alone. Moreover, the mAb to CD40L, in contrast to the control $\mathrm{mAb}$, could block significantly the $\mathrm{T}$ cell augmented production of the IgG autoantibodies by PBMC of lupus patients with active and established disease (Table IV). In the six lupus patients tested, the anti-CD40L mAb blocked (mean \pm SEM of percent inhibition) IgG anti-ssDNA production by $39.9 \pm 9.7 \%$, IgG anti-dsNDA by $67.9 \pm 9.3 \%$, and $\mathrm{IgG}$ antinucleosome autoantibodies by $71.8 \pm 10.6 \%$. All of the patients began to receive steroids and/or cytoxan therapy for their active disease soon after the blood samples were obtained for these assays. The anti-CD40L-mediated inhibition of pathogenic autoantibody production, especially autoantibodies to dsDNA and nucleosomes, could still be detected in a patient who agreed to donate blood again for a repeat assay (EB and EB-2 in Table IV).

In the case of three of the patients (EB, SC, and VC), the

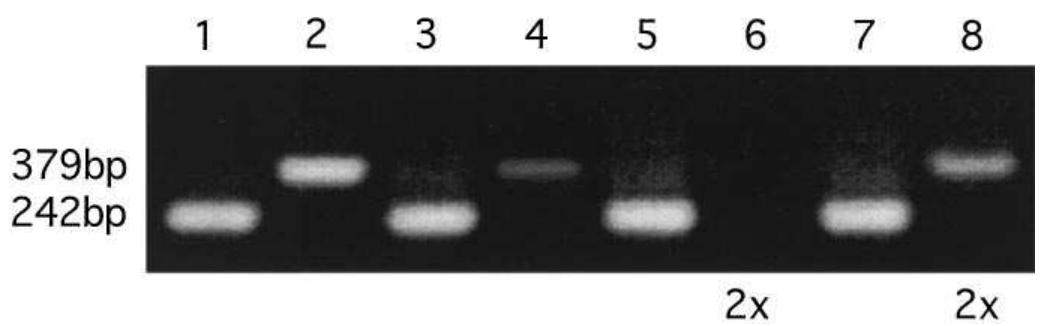

Figure 5. Expression of endogenous CD40L message by B cells. Lanes 1 and 2 show PCR-amplified products from anti-CD3-stimulated normal T cells from a CD4 ${ }^{+}$ $\mathrm{T}$ cell line; lanes 3 and 4 are from an active lupus patient's B cells that were purified but unstimulated ex vivo; lanes 5 and 6 are from purified, normal B cells that were stimulated with anti-CD3; and lanes 7 and 8 are from purified, normal B cells that were stimulated by SAC and IL-2. The amplified CD40L band is $379 \mathrm{bp}$ (lanes 2, 4, 6 and 8 ), and the constitutively expressed HLA-DQ band is 242 bp (lanes 1, 3, 5 and 7). Lanes 1, 2, 3, 4, 5 and 7 show the products of a single-step PCR amplification whereas lanes 6 and 8 show the results after a second PCR amplification, designated by $2 \times(30$ additional cycles $)$. Unstimulated T cells from the T cell lines after resting for $10 \mathrm{~d}$ and unstimulated B cells from the normal subject did not express CD40L message that could be detected by PCR (not shown). 


\begin{tabular}{|c|c|c|c|c|}
\hline \multirow[b]{3}{*}{ Culture conditions* } & \multicolumn{4}{|c|}{ Percentage of $\mathrm{CD} 4^{+} \mathrm{T}$ cells that expressed: } \\
\hline & \multicolumn{2}{|c|}{ Lupus $\mathrm{T}$ cell line } & \multicolumn{2}{|c|}{ Normal T cell line } \\
\hline & $\mathrm{CD} 40 \mathrm{~L}$ & CD69 & $\mathrm{CD} 40 \mathrm{~L}$ & CD69 \\
\hline Unstimulated & 9.50 & 11.84 & 0.35 & 7.13 \\
\hline$[\mathrm{P}+\mathrm{I}]$ & 80.80 & 96.56 & 72.20 & 97.95 \\
\hline$[\mathrm{P}+\mathrm{I}] \rightarrow[\mathrm{EBV}-\mathrm{BCL} / \mathrm{c}-\mathrm{mAb}]$ & 11.72 & ND & 22.48 & 98.33 \\
\hline$[\mathrm{P}+\mathrm{I}] \rightarrow[\mathrm{EBV}-\mathrm{BCL} / \alpha-\mathrm{CD} 40]$ & 78.10 & ND & 86.34 & 98.07 \\
\hline$[\alpha-\mathrm{CD} 3]$ & 25.00 & 48.69 & 2.22 & 60.46 \\
\hline$[\alpha-\mathrm{CD} 3] \rightarrow[\mathrm{EBV}-\mathrm{BCL} / \mathrm{c}-\mathrm{mAb}]$ & 0.48 & ND & 0.12 & ND \\
\hline$[\alpha-\mathrm{CD} 3] \rightarrow[\mathrm{EBV}-\mathrm{BCL} / \alpha-\mathrm{CD} 40]$ & 17.10 & ND & 2.63 & ND \\
\hline
\end{tabular}

*Short-term $\mathrm{T}$ cell lines derived from $\mathrm{CD} 4^{+} \mathrm{T}$ cells of lupus patients or normal subjects were rested first (unstimulated) and then used for the different culture conditions, followed by two-color staining with either anti-CD4 and anti-CD40L or anti-CD4 and anti-CD69 mAbs. Representative examples from studies on short-term lines derived from six patients with active lupus and three normal subjects are shown. [P+I] means PMA + ionomycin stimulation. As indicated, in separate cultures $[\mathrm{P}+\mathrm{I}]$ stimulation was followed by $(\rightarrow)$ coculture with either EBV-BCL preincubated with anti-CD40 $(\alpha-C D 40)$ or EBV-BCL preincubated with isotype matched control (c-mAb). Anti-CD3 ( $\alpha-C D 3)$ mAb was used at 1:125 dilution. ND means not done, as it is known that CD69 expressed by activated T cells cannot be downmodulated by CD40 on EBV-BCL (references 45-47, and data on extreme right column).

production of $\mathrm{IgG}$ autoantibodies was preferentially blocked by anti-CD40L as compared to total polyclonal $\mathrm{IgG}$ which is produced at much higher levels than the autoantibodies in culture (Table IV). Whereas in the other patients, the production of total IgG was also markedly inhibited along with the autoantibodies. The anti-CD40L mAb (or the control $\mathrm{mAb}$ ) was present in the PBMC cultures throughout the 13-d culture period (see Methods).

\section{Discussion}

These findings on CD40-CD40L interaction in human SLE, some of which are quite unexpected, have implications for understanding the etiologic mechanisms of this disease as well as for developing specific immunotherapy. The increase in expression of CD40L by CD4 ${ }^{+} \mathrm{T}$ cells that occurs spontaneously in the patients with active lupus, resembles our results in murine lupus (48). In contrast to normal mice, lupus mice had much higher levels of CD40L-expressing T cells even at the preautoimmune age of 1 mo (48). Moreover, as shown here, the superinduction of CD40L on mitogenic stimulation of the lupus patient's T cells, even during remission of the disease, in- dicates a defect in the regulation of CD40L expression. This interpretation is consistent with abnormalities in other signal transduction pathways that have been detected in the $\mathrm{T}$ cells of lupus $(51,52)$. The hyperexpression of CD40L by the lupus $\mathrm{T}$ and $\mathrm{B}$ cells persisted during the prolonged culture of the lupus PBMC in vitro (data not shown), most probably because of continued $\mathrm{T}-\mathrm{B}$ interaction and rounds of stimulation in the culture mixture. However, in short-term $\mathrm{CD} 4^{+} \mathrm{T}$ cell lines, the superinduction of CD40L by mitogenic stimulation of the lupus T cells could be downmodulated by CD40 on autologous B cell lines, indicating that this negative feedback mechanism is still intact in lupus as in normal T cells (45-47).

The augmented expression of CD40L by $\mathrm{CD} 8^{+} \mathrm{T}$ cells in active lupus is another interesting finding, because it may explain the unusual helper activity of $\mathrm{T}$ cells with this phenotype in lupus $(13,21)$. Interestingly, $\mathrm{CD}^{+} \mathrm{T}$ helper cells were found subsequently in patients with AIDS that produce high levels of polyclonal Ig, including autoantibodies (53).

The most unexpected finding was the hyperexpression of CD40L by lupus B cells. It is widely accepted that CD40L expressed only by activated $\mathrm{CD}^{+}$Th cells has any functional consequence. Indeed in normal mice, CD40L expression by $\mathrm{T}$

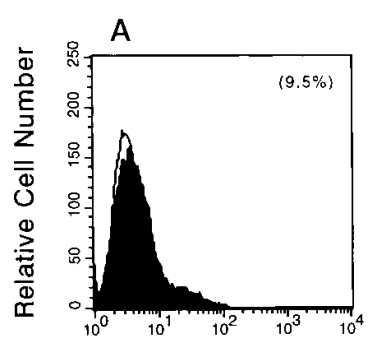

B
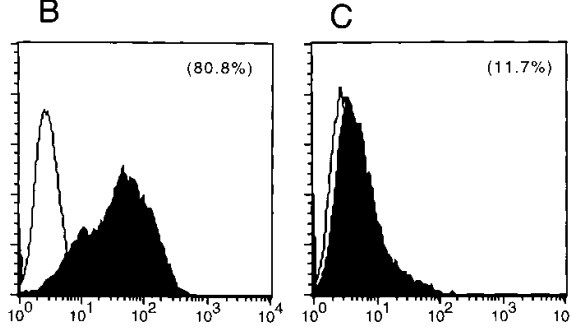

D

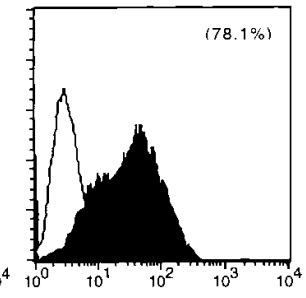

CD40L Fluorescence

Figure 6. CD40 on B cells down-modulates CD40L expression by lupus $\mathrm{T}$ cells. Representative example of a histogram showing CD40L fluorescence (solid black) of gated $\mathrm{CD} 4^{+} \mathrm{T}$ cells. $\mathrm{CD}^{+}{ }^{+} \mathrm{T}$ cells from short-term $\mathrm{T}$ cell line from a patient with active lupus were analyzed for $\mathrm{CD} 40 \mathrm{~L}$ expression under the following conditions: $(A)$ at rest; $(B)$ after stimulation for $8 \mathrm{~h}$ with PMA and ionomycin; $(C)$ same as in $B$ except autologous EBV-BCL B cells (pretreated with a control $\mathrm{mAb}$ ) were added to the $\mathrm{T}$ cells in the last $2 \mathrm{~h}$ before staining; and $(D)$ same as in $C$ except for pretreatment of the EBV-BCL with anti-CD40 mAb before adding to the stimulated $\mathrm{T}$ cells. 


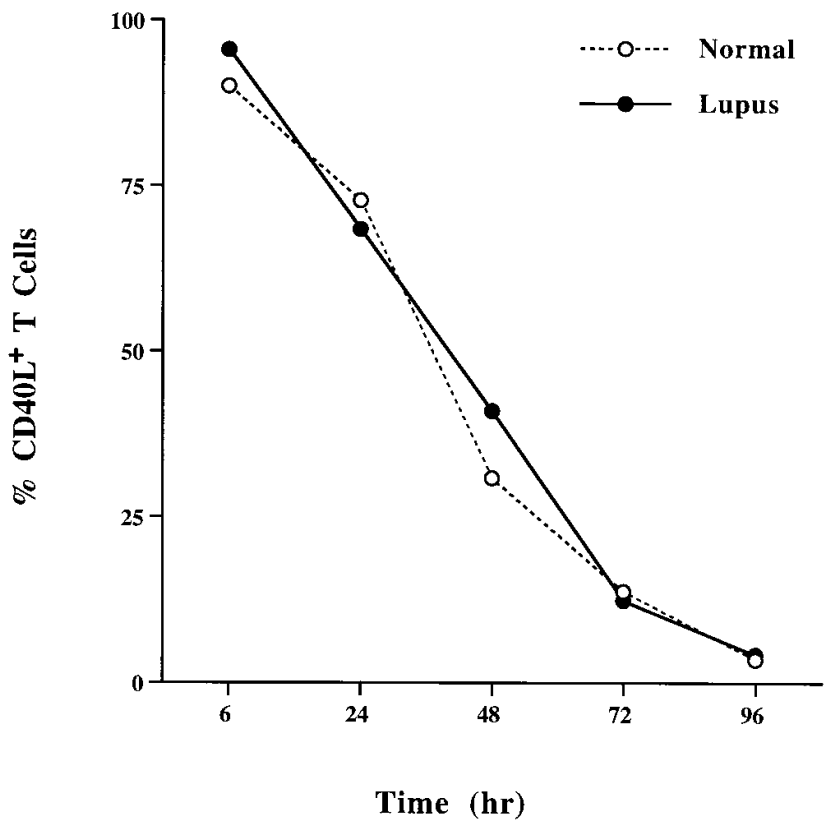

Figure 7. Kinetics of CD40L expression after PMA + ionomycin stimulation are similar in normal and lupus $\mathrm{T}$ cells. A representative experiment is shown. T cells from short-term lines of an active lupus and a normal subject at different time points after the stimulation were stained for $\mathrm{CD} 4$ and $\mathrm{CD} 40 \mathrm{~L}$ and the percent CD40L-expressing $\mathrm{CD}^{+} \mathrm{T}$ cells are shown. Herein, no EBV-BCL B cells were added to the $\mathrm{T}$ cells.

cells only appears to be of any functional consequence in vivo (54). Recently however, while we were making these observations in lupus, Grammer et al. reported the expression of CD40L by normal human B cells (44). Our results with normal $B$ cells confirm those observations. In addition, herein we found important differences in lupus B cells. Normal human B cells have to be coaxed by pharmacologic manipulations, such as a combination of calcium ionophore, phorbol ester, and IL-2 to express CD40L, and even then the level of expression is markedly less than activated $\mathrm{T}$ cells (44). In contrast, lupus patients' B cells spontaneously express CD40L in levels as high as activated T cells. Furthermore, mitogen-stimulated upregulation of $\mathrm{CD} 40 \mathrm{~L}$ is markedly greater in lupus $\mathrm{T}$ and $\mathrm{B}$ cells, even during remission of the disease, suggesting that a defect in SLE has lowered the threshold for CD40L expression, in addition to autoantigen-driven activation. None of the patients in remission were receiving any cytotoxic drugs or steroids, and the levels of $\mathrm{CD}^{+} 9^{+}$(activated) $\mathrm{T}$ cells in their peripheral blood were in the range of normal subjects. Thus the lymphocytes of remission patients were not in a state of chronic activation by this criteria, and yet CD40L was hyperinducible in these patients' $\mathrm{T}$ and $\mathrm{B}$ cells, suggesting an intrinsic abnormality.

CD40L is endogenously produced by the B cells; it does not appear to be passively acquired from the activated $\mathrm{Th}$ cells. The intensities of CD40L expression were similar in the $\mathrm{B}$ and T cells of lupus (Figs. 1-4). Stimulation with B cell mitogen (SAC and IL-2) caused a further increase in CD40L expression by $B$ cells from patients with active lupus and markedly more so by B cells from remission patients (Figs. 3 and 4), and the CD40L staining could not be removed by acid-wash of the B cells (data not shown, but similar to reference 44). Fur- thermore, NK cells in the PBMC of lupus patients did not stain positively for CD40L (data not shown), again indicating that passively acquired CD40L shed from $\mathrm{T}$ cells is not a significant phenomenon. When CD40-expressing EBV-BCL B cells were cocultured with activated $\mathrm{T}$ cells expressing CD40L, the former cells did not pick up CD40L from the T cells; all the cells that stained for CD40L in such cocultures were CD4 ${ }^{+}$(Fig. 6 and dot plots not shown). Finally, PCR for CD40L mRNA showed that highly purified B cells from normal subjects express CD40L only upon stimulation with $\mathrm{B}$ cell mitogens but not a $\mathrm{T}$ cell mitogen (Fig. 5). This result again indicates that CD40L expression is endogenously upregulated by activated $\mathrm{B}$ cells and is not passively acquired from T cells. Further studies will determine whether the increase in CD40L mRNA in lupus $\mathrm{B}$ cells (Fig. 5) is due to increased transcription or due to increased stability of CD40L mRNA (55).

In contrast to other anti-human mAb, 5c8 and 4D9-9 (44), the mAb (clone 24-31) used here can detect CD40L on human $B$ cells ex vivo without any acid treatment, suggesting that unlike the $5 \mathrm{c} 8$ epitope which may be masked by soluble CD40, the 24-31 (anti-CD40L) mAb detects another epitope that remains exposed. This feature may be therapeutically important in the future.

Thus in addition to being activated and costimulated by CD40L on Th cells, the lupus B cells could amplify and sustain the pathogenic autoimmune response further by expressing CD40L and thus interacting with CD40 on other autoimmune $\mathrm{B}$ cells in the vicinity as well as follicular dendritic cells in the germinal center $(44,56)$. Moreover, a bidirectional interaction between the $\mathrm{CD} 40 \mathrm{~L}^{+} \mathrm{B}$ cells and the Th cells might occur in lupus, since CD40 itself might be expressed by activated T cells (57). Nucleosomal autoantigen presentation by the autoimmune $B$ cells to the pathogenic Th cells $(15,18)$ could be markedly augmented by such $\mathrm{T}-\mathrm{B}$ and $\mathrm{B}-\mathrm{B}$ interactions, since signaling by CD40L upregulates the B7 family of molecules on $\mathrm{B}$ cells which would in turn costimulate the cognate Th cells via CD28/CTLA4 $(32,58,59)$. However, the hyperexpression of CD40L by lupus B cells is not sufficient by itself to mediate an increase in pathogenic autoantibody production, at least in vitro (Table IV). Probably, the focused delivery of Th cytokines at a close range to the autoantibody producing $\mathrm{B}$ cells during their cognate contact-dependent interaction with the lupus Th cells is still required for pathogenic autoantibody production (Table IV). Nevertheless, the hyperexpression of CD40L by lupus B cells could increase B-B cell interaction via CD40 and thus prevent apoptosis or anergy of autoimmune B cells and make them more susceptible to pathogenic $\mathrm{T}$ cell help. The amazingly long-term benefit of a very brief antiCD40L therapy in a mouse model of lupus (48) is consistent with the importance of CD40L-CD40 interactions in a variety of cells in the immune system that lead to pathogenic autoantibody production in SLE. However, the increased or aberrant CD40L expression is not global in SLE, NK cells did not express CD40L in patients with active lupus (data not shown).

The long-term beneficial effect of a brief anti-CD40L therapy in lupus mice (48) is relevant to our findings in human SLE. The effect of anti-CD40L in the mice was most probably mediated by checking the expansion the autoimmune memory $\mathrm{B}$ cells that are committed to produce pathogenic autoantibodies, since the brief therapy did not affect the Th cells in the long term (48). In the natural history of lupus, once the autoimmune memory B cells are generated they may further am- 
Table IV. Anti-CD40L mAb Inhibits the Production of Pathogenic Autoantibodies by Cells from Active Lupus Patients

\begin{tabular}{|c|c|c|c|c|c|}
\hline \multirow[b]{2}{*}{ Lupus patient } & \multirow[b]{2}{*}{ Culture condition ${ }^{\ddagger}$} & \multicolumn{4}{|c|}{ IgG antibody production in culture* } \\
\hline & & $\alpha$-ssDNA & $\alpha$-dsDNA & $\alpha$-Nucleosome & Total IgG \\
\hline & & $U / m l$ & $U / m l$ & $U / m l$ & $\mu g / m l$ \\
\hline \multirow[t]{4}{*}{ EB } & B cells alone & 0.105 & 0.038 & 0 & 0.220 \\
\hline & $\mathrm{PBMC}+\mathrm{c}-\mathrm{IgG} 1$ & 0.235 & 0.099 & 0.034 & 1.148 \\
\hline & $\mathrm{PBMC}+\alpha-\mathrm{CD} 40 \mathrm{~L}$ & 0.185 & 0.012 & 0 & 1.094 \\
\hline & Percent inhibition & 21.3 & 87.9 & 100 & 4.7 \\
\hline \multirow[t]{4}{*}{$\mathrm{SC}$} & B cells alone & 0.070 & 0 & 0 & 1.729 \\
\hline & $\mathrm{PBMC}+\mathrm{c}-\mathrm{IgG} 1$ & 0.100 & 0.074 & 0.022 & 2.315 \\
\hline & $\mathrm{PBMC}+\alpha-\mathrm{CD} 40 \mathrm{~L}$ & 0.046 & 0.030 & 0 & 2.152 \\
\hline & Percent inhibition & 54 & 59.5 & 100 & 7 \\
\hline \multirow[t]{4}{*}{$\mathrm{RC}$} & B cells alone & 0.359 & 0.046 & 0.125 & 0.361 \\
\hline & $\mathrm{PBMC}+\mathrm{c}-\mathrm{IgG} 1$ & 0.700 & 0.285 & 0.883 & 2.097 \\
\hline & $\mathrm{PBMC}+\alpha-\mathrm{CD} 40 \mathrm{~L}$ & 0.306 & 0.024 & 0.233 & 0.043 \\
\hline & Percent inhibition & 56.3 & 91.6 & 73.6 & 97.9 \\
\hline \multirow[t]{4}{*}{$\mathrm{VC}$} & $\mathrm{B}$ cells alone & 0.025 & 0.015 & 0 & 1.050 \\
\hline & PBMC + c-IgG1 & 0.353 & 0.112 & 0.098 & 1.440 \\
\hline & $\mathrm{PBMC}+\alpha-\mathrm{CD} 40 \mathrm{~L}$ & 0.147 & 0.039 & 0.028 & 1.186 \\
\hline & Percent inhibition & 58.4 & 65.2 & 71.4 & 17.6 \\
\hline \multirow[t]{4}{*}{$\mathrm{IH}$} & B cells alone & ND & ND & ND & ND \\
\hline & PBMC + c-IgG1 & 0.101 & 0.134 & 0.094 & 10.158 \\
\hline & $\mathrm{PBMC}+\alpha-\mathrm{CD} 40 \mathrm{~L}$ & 0.109 & 0.035 & 0.047 & 2.439 \\
\hline & Percent inhibition & 0 & 73.9 & 50 & 76 \\
\hline \multirow[t]{4}{*}{ BM } & B cells alone & 0.032 & 0.020 & 0 & 0.375 \\
\hline & PBMC + c-IgG1 & 0.284 & 0.559 & 0.465 & 1.793 \\
\hline & $\mathrm{PBMC}+\alpha-\mathrm{CD} 40 \mathrm{~L}$ & 0.143 & 0.397 & 0.299 & 1.176 \\
\hline & Percent inhibition & 49.6 & 29 & 35.7 & 34.4 \\
\hline \multirow[t]{4}{*}{ EB-2 } & B cells alone & 0.029 & 0 & 0.003 & 0.311 \\
\hline & PBMC + C-IgG1 & 0.144 & 0.096 & 0.102 & 2.315 \\
\hline & $\mathrm{PBMC}+\alpha-\mathrm{CD} 40 \mathrm{~L}$ & 0.135 & 0.036 & 0.060 & 2.025 \\
\hline & Percent inhibition & 6.3 & 62.5 & 41.2 & 12.5 \\
\hline
\end{tabular}

$¥ 3 \times 10^{5} \mathrm{PBMC}$ (contains both $\mathrm{T}$ and $\mathrm{B}$ cells) or $1 \times 10^{5} \mathrm{~B}$ cells alone were cultured per microwell. c-IgG1 means control IgG1 that is isotype-matched to the anti-CD40L mAb $(\alpha-\mathrm{CD} 40 \mathrm{~L})$. Values of percent inhibition of IgG antibody production by PBMC with $\alpha-\mathrm{CD} 40 \mathrm{~L}$ are shown.*IgG autoantibodies are expressed in units per milliliter based on reference serum standard. $\alpha$ - means anti-. ND, not done. Total IgG is expressed in micrograms per milliliter as it is produced in much higher amounts than the autoantibodies in the culture.

plify the autoimmune response by efficiently presenting nucleosomal peptides $(15,18)$ and subsequently by "epitope spreading" present autoantibody idiotype-derived peptides to pathogenic Th cells (60). The brief anti-CD40L therapy probably also checked this amplification process. Moreover, the anti-CD40L therapy in lupus mice (48), although brief, could render autoimmune $\mathrm{B}$ cells tolerogenic by diminishing their costimulatory ability and antigen-presenting cell function (32, $54,58,59)$.

These studies also suggest that the pathogenic B cells of lupus can be downregulated and that they are not totally autonomous due to some intrinsic defect. The autoimmune B cells of most murine models of lupus (except MRL-lpr), as well as human SLE, may be as susceptible to apoptosis as normal antigen-driven B cells unless they are rescued by the CD40-mediated second signal $(38,40-42,61)$. However, B cells capable of producing pathogenic anti-DNA autoantibodies are not deleted in the bone marrow; they are present in the periphery of normal subjects, and they can be expanded by various means to produce nephritogenic autoantibodies $(5,7,62-66)$. Thus the factors determining the peripheral drive and cognate $\mathrm{Th}$ cell-induced pathogenic autoantibody production are relevant to understanding the basic mechanism of SLE.

Herein, the antibody to CD40L could block in vitro the production of $\mathrm{IgG}$ autoantibodies by cells from lupus patients with established and active disease. The anti-CD40L mAb was present in the culture for the entire period of $13 \mathrm{~d}$; thus it also inhibited total polyclonal $\mathrm{IgG}$ production significantly in some of the patients. Th cells specific for other exogenous antigens, in addition to the autoimmune Th cells, were probably activated in those patients at the time blood sample was obtained and again during the prolonged culture period. Nevertheless, it is encouraging that significant blocking of pathogenic antiDNA autoantibodies occurred in all patients tested even after the autoantibody-producing B cells and their Th cells had already been triggered in vivo in these patients with active and 
established disease. This result suggests that the pathogenic Th and $B$ cells of lupus undergo repeated cycles of activation and rest or different waves of activated cells participated in the production of pathogenic autoantibodies during the 13-d culture period. Interestingly, a brief anti-CD40L therapy given at early stages of lupus in mice preferentially blocks the pathogenic autoimmune response in vivo, but it does not cause generalized immunosuppression (48). This beneficial result could be due to the fact that CD40L is transiently expressed on activated $\mathrm{T}$ cells, and in the lupus mice, most of the $\mathrm{T}$ cells that are activated are the Th cells that drive B cells to make pathogenic autoantibodies. Indeed, anti-CD40L therapy was beneficial even at the time early autoimmune abnormalities were manifest in the lupus mice. This suggests that anti-CD40L therapy might be beneficial in newly diagnosed lupus patients or in patients in the early stages of disease flare-up. Interestingly, blocking B7-CTLA4/CD28 interaction by CTLA4Ig also has a beneficial effect on murine lupus (67), probably through its indirect effect on the CD40L-CD40 signaling pathway $(32,68)$.

These studies in human and murine SLE should stimulate the development of anti-CD40L therapy in human lupus (69). We are even more interested in understanding why CD40L expression is deregulated in the B and T cells of lupus? It appears to be an intrinsic defect and not merely or wholly due to autoantigenic activation. Remarkably, the defect in the regulation of CD40L is present in lupus patients even during remission of the disease. Future studies on CD40L regulation could elucidate the mechanisms of intrinsic $\mathrm{T}$ and $\mathrm{B}$ cell defects in lupus.

\section{Acknowledgments}

We thank Tonya Robinson for technical assistance. This work will form part of A. Desai-Mehta's Ph.D. thesis for Sackler Graduate Immunology Programme, Tufts University School of Medicine, Boston, MA.

This work was supported by The American Lupus Society and National Institutes of Health grants CA31789 and AR39157 to S.K. Datta and AR30692 to R.R. Goldman.

\section{References}

1. Rothfield, N.F., and B.D. Stollar. 1967. The relation of immunoglobulin class, pattern of antinuclear antibody, and complement-fixing antibodies to DNA in sera from patients with systemic lupus erythematosus. J. Clin. Invest. 46:1785-1794.

2. Burlingame, R.W., M.L. Boey, G. Starkebaum, and R.L. Rubin. 1994 The central role of chromatin in autoimmune responses to histones and DNA in systematic lupus erythematosus. J. Clin. Invest. 94:184-192.

3. Suzuki, N., T. Harada, Y. Mizushima, and T. Sakane. 1993. Possible pathogenic role of cationic anti-DNA autoantibodies in the development of nephritis in patients with systemic lupus erythematosus. J. Immunol. 151:11281136.

4. Suenaga, R., and N.I. Abdou. 1993. Cationic and high affinity serum IgG anti-dsDNA antibodies in active lupus nephritis. Clin. Exp. Immunol. 94:418422.

5. Diamond, B., J.B. Katz, E. Paul, C. Aranow, D. Lustgarten, and M.D. Scharff. 1992. The role of somatic mutation in the pathogenic anti-DNA response. Annu. Rev. Immunol. 10:731-757.

6. Sabbaga, J., O.G. Pankewycz, V. Lufft, R.S. Schwartz, and M.P. Madaio. 1990. Cross-reactivity distinguishes serum and nephritogenic anti-DNA antibodies in human lupus from their natural counterparts in normal serum. $J$. $\mathrm{Au}$ toimmun. 3:215-235.

7. Rubin, R.L., R.W. Burlingame, and J.E. Arnott. 1995. IgG but not other classes of anti- $[<\mathrm{H} 2 \mathrm{~A}-\mathrm{H} 2 \mathrm{~B}>-\mathrm{DNA}]$ is an early sign of procainamide-induced lupus. J. Immunol. 154:2483-2493.

8. Gavalchin, J., and S.K. Datta. 1987. The NZB $\times$ SWR model of lupus nephritis. II. Autoantibodies deposited in renal lesions show a restricted idiotypic diversity. J. Immunol. 138:138-148.

9. Burlingame, R.W., R.L. Rubin, R.S. Balderas, and A.N. Theofilopoulos. 1993. Genesis and evolution of antichromatin autoantibodies in murine lupus implicates immunization with self antigen. J. Clin. Invest. 91:1687-1696.

10. Di Valerio, R., K.A. Bernstein, E. Varghese, and J.B. Lefkowith. 1995. Murine lupus glomerulotropic monoclonal antibodies exhibit differing specificities but bind via a common mechanism. J. Immunol. 155:2258-2268.

11. Datta, S.K., H. Patel, and D. Berry. 1987. Induction of a cationic shift in IgG anti-DNA autoantibodies. Role of T helper cells with classical and novel phenotypes in three murine models of lupus nephritis. J. Exp. Med. 165:12521268 .

12. Sainis, K., and S.K. Datta. 1988. CD4 $4^{+} \mathrm{T}$ cell lines with selective patterns of autoreactivity as well as $\mathrm{CD} 4^{-} / \mathrm{CD}^{-} \mathrm{T}$ helper cell lines augment the production of idiotypes shared by pathogenic anti-DNA autoantibodies in the NZB $\times$ SWR model of lupus nephritis. J. Immunol. 140:2215-2224.

13. Shivakumar, S., G.C. Tsokos, and S.K. Datta. 1989. T cell receptor $\alpha / \beta$ expressing double negative $\left(\mathrm{CD} 4^{-} / \mathrm{CD}^{-}\right)$and $\mathrm{CD}^{+} \mathrm{T}$ helper cells in humans augment the production of pathogenic anti-DNA autoantibodies associated with lupus nephritis. J. Immunol. 143:103-112.

14. Rajagopalan, S., T. Zordan, G.C. Tsokos, and S.K. Datta. 1990. Pathogenic anti-DNA autoantibody inducing $\mathrm{T}$ helper cell lines from patients with active lupus nephritis: Isolation of $\mathrm{CD}^{-} / \mathrm{CD}^{-} \mathrm{T}$ helper cell lines that express the $\gamma / \delta$ T-cell receptor. Proc. Natl. Acad. Sci. USA. 87:7020-7024.

15. Desai-Mehta, A., C. Mao, S. Rajagopalan, T. Robinson, and S.K. Datta 1995. Structure and specificity of T cell receptors expressed by potentially pathogenic anti-DNA autoantibody-inducing T cells in human lupus. J. Clin. Invest. 95:531-541.

16. Adams, S., P. Leblanc, and S.K. Datta. 1991. Junctional region sequences of T-cell receptor $\beta$ chain genes expressed by pathogenic anti-DNA autoantibody-inducing $\mathrm{T}$ helper cells from lupus mice: possible selection by cationic autoantigens. Proc. Natl. Acad. Sci. USA. 88:11271-11275.

17. Mao, C., G.E. Osman, S. Adams, and S.K. Datta. 1993. Nucleosome: a major immunogen for the pathogenic autoantibody-inducing $\mathrm{T}$ cells in lupus mice. J. Immunol. 152:1462-1470.

18. Mohan, C., S. Adams, V. Stanik, and S.K. Datta. 1993. Nucleosome: a major immunogen for the pathogenic autoantibody-inducing T cells of lupus. $J$. Exp. Med. 177:1367-1381.

19. Ando, D.G., E.E. Sercarz, and B.H. Hahn. 1987. Mechanisms of T and $\mathrm{B}$ cell collaboration in the in vitro production of anti-DNA antibodies in the NZB/NZW F1 murine SLE model. J. Immunol. 138:3185-3190.

20. Naiki, M., B.-L. Chiang, D. Cawley, A. Ansari, S.J. Rozzo, B.L. Kotzin, A. Zlotnik, and M.E.. Gershwin. 1992. Generation and characterization of cloned helper $\mathrm{T}$ cell lines for anti-DNA responses in NZB.H-2bm12 mice. $J$. Immunol. 149:4109-4115.

21. Linker-Israeli, M., F.P. Quisimoro, and D.A. Horwitz. 1990. CD8 ${ }^{+}$lymphocytes from patients with systemic lupus erythematosus sustain, rather than suppress, spontaneous polyclonal IgG production and synergize with $\mathrm{CD}^{+}$ cells to support autoantibody synthesis. Arthritis \& Rheum. 33:1216-1225.

22. Crow, M.K., G. Delguidice-Ash, J.B. Zehetbauer, N. Lawson, H. Brot, H. Weissbach, and K.B. Elkon. 1994. Autoantigen specific T cell proliferation induced by ribosomal $\mathrm{P} 2$ protein in patients with systemic lupus erythematosus. J. Clin. Invest. 94:345-352.

23. Kuwana, M., T.A. Medsger, and T.M. Wright. 1995. T and B cell collaboration is essential for autoantibody response to DNA Topoisomerase I in systemic sclerosis. J. Immunol. 155:2703-2714.

24. Mamula, M.J., S. Fatenejad, and J. Craft. 1994. B cells process and present lupus autoantigens that initiate autoimmune T cell responses. J. Immunol. 152:1453-1461.

25. Sobel, E.S., V.N. Kakkanaiah, M. Kakkanaiah, R.L. Cheek, P.L. Cohen, and R.A. Eisenberg. 1994. T-B collaboration for autoantibody production in lpr mice is cognate and MHC-restricted. J. Immunol. 152:6011-6016.

26. Klinman, D.M., and A.D. Steinberg. 1987. Systemic autoimmune disease arises from polyclonal B cell activation. J. Exp. Med. 165:1755-1760.

27. Reininger, L., T. Radaszkiewicz, M. Kosco, F. Melchers, and A.G Rolnik. 1992. Development of autoimmune disease in SCID mice populated with long-term in vitro proliferating $(\mathrm{NZB} \times \mathrm{NZW}) \mathrm{F} 1$ pre-B cells. J. Exp. Med. 176:1343-1353.

28. Datta, S.K., F.L. Owen, J.E. Womack, and R.J. Riblet. 1982. Analysis of recombinant inbred lines derived from autoimmune (NZB) and high leukemia (C58) strains: independent multigenic systems control B cell hyperactivity, retrovirus expression and autoimmunity. J. Immunol. 129:1539-1544.

29. Merino, R., M. Iwamoto, L. Fossati, and S. Izui. 1993. Polyclonal B cell activation arises from different mechanisms in lupus-prone $(\mathrm{NZB} \times \mathrm{NZW}) \mathrm{F} 1$ and MRL/Mpj-lpr/lpr mice. J. Immunol. 151:6509-6516.

30. Noelle, R.J., M. Roy, D.M. Shepherd, I. Stamencovic, J.A. Ledbetter, and A. Aruffo. 1992. A novel ligand on activated helper T cells binds CD40 and transduces the signal for the cognate activation of B cells. Proc. Natl. Acad. Sci. USA. 89:6550-6554.

31. Lederman, S., M.J. Yellin, G. Inghirami, J.J. Lee, D.M. Knowles, and L. Chess. 1992. Molecular interaction mediating T-B lymphocyte collaboration in human lymphoid follicles. Role T cell-B cell activating molecule (5c8 antigen) and CD40 in contact-dependent help. J. Immunol. 149:3817-3826.

32. Clark, E.A., and J.A. Ledbetter. 1994. How B and T cells talk to each other. Nature (Lond.). 367:425-428.

33. Roy, M., T. Waldschmidt, A. Aruffo, J.A. Ledbetter, and R.J. Noelle. 
1993. The regulation of the expression of gp39, the CD40 ligand, on normal and cloned CD4+ T cells. J. Immunol. 151:2497-2510.

34. Ren, C.L., T. Morio, S.M. Fu, and R.S. Geha. 1994. Signal transduction via CD40 involves activation of lyn kinase and phosphatidylinositol-3-kinase, and phosphorylation of phospholipase C $\gamma 2$. J. Exp. Med. 179:673-680.

35. Faris, M., F. Gaskin, J.T. Parsons, and S.M. Fu. 1994. CD40 signaling pathway: anti-CD40 monoclonal antibody induces rapid dephosphorylation and phosphorylation of Tyrosine-phosphorylated proteins including protein tyrosine kinase Lyn, Fyn, and Syk and the appearance of a $28-\mathrm{kD}$ tyrosine phosphorylated protein. J. Exp. Med. 179:1923-1931.

36. Banchereau, J., F. Bazan, D. Blanchard, F. Briere, J.P. Galizi, C. van Kooten, Y.J. Liu, F. Rousset, and S. Saeland. 1994. The CD40 antigen and its ligand. Annu. Rev. Immunol. 12:881-922.

37. Spriggs, M.K., R.J. Armitage, L. Stockbine, K.N. Clifford, B.M. Macduff, T.A. Sato, C.R. Maliszewski, and W.C. Fanslow. 1992. Recombinant human CD40 ligand stimulates B cell proliferation and immunoglobulin E secretion. J. Exp. Med. 176:1543-1550.

38. Lederman, S., M.J. Yellin, A.M. Cleary, A. Pernis, G. Inghirami, L.E. Chon, L.R. Covey, J.L. Lee, P. Rothman, and L. Chess. 1994. T-BAM/CD40-L on helper T lymphocytes augments lymphokine-induced B cell Ig isotype switch recombination and rescues B cells from programmed cell death. J. Immunol. 152:2163-2171.

39. Foy, T.M., J.D. Laman, J.A. Ledbetter, A. Aruffo, E. Claassen, and R.J. Noelle. 1994. gp39-CD40 interactions are essential for germinal center formation and the development of B cell memory. J. Exp. Med. 180:157-163.

40. Liu, Y.-J., D.E. Joshua, G.T. Williams, C.A. Smith, J. Gordon, and I.C.M. MacLennan. 1989. Mechanism of antigen driven selection in germinal centers. Nature (Lond.). 342:929-931.

41. Tsubata, T., J. Wu, and T. Honjo. 1993. B cell apoptosis induced by antigen receptor crosslinking is blocked by a T cell signal through CD40. Nature (Lond.). 364:645-648.

42. Wang, Z., J.G. Karras, R.G. Howard, and T.L. Rothstein. 1995. Induction of bcl-x by CD40 engagement rescues sIg-induced apoptosis in murine B cells. J. Immunol. 155:3722-3725.

43. Liang, M.H., S.A. Socher, M.G. Larson, and P.H. Schur. 1989. Reliability and validity of six systems for the clinical assessment of disease activity in systemic lupus erythematosus. Arthritis \& Rheum. 32:1107-1118.

44. Grammer, A.C., M.C. Bergman, Y. Miura, K. Fujita, L.S. Davis, and P.E. Lipsky. 1995. The CD40 ligand expressed by human B cells costimulates B cell responses. J. Immunol. 154:4996-5010.

45. Castle, B.E., K. Kishimoto, C. Stearns, M.L. Brown, and M.R. Kehry. 1993. Regulation of expression of the ligand for CD40 on T helper lymphocytes. J. Immunol. 151:1777-1788.

46. Yellin, M.J., K. Sippel, G. Inghirami, L.R. Covey, J.J. Lee, J. Sinning. E.A. Clark, L. Chess, and S. Lederman. 1994. CD40 molecules induce downmodulation and endocytosis of $\mathrm{T}$ cell surface $\mathrm{T}$ cell-B cell activating molecule/ CD40-L. J. Immunol. 152:598-608.

47. van Kooten, C.V., C. Gaillard, J.-P. Gallizi, P. Hermann, F. Fossiez, J. Banchereau, and D. Blanchard. 1994. B cells regulate expression of CD40 ligand on activated $\mathrm{T}$ cells by lowering the mRNA level and through the release of soluble CD40. Eur. J. Immunol. 24:787-792.

48. Mohan, C., Y. Shi, J.D. Laman, and S.K. Datta. 1995. Interaction between CD40 and its ligand gp39 in the development of murine lupus nephritis. J. Immunol. 154:1470-1480.

49. Gyllensten, U.B., and H.A. Erlich. 1988. Generation of single stranded DNA by the polymerase chain reaction and its application to direct sequencing of the HLA-DQA locus. Proc. Natl. Acad. Sci. USA. 85:7652-7656.

50. Nonoyama, S., L.A. Penix, C.P. Edwards, D.B. Lewis, S. Ito, A. Aruffo, C.B. Wilson, and H.D. Ochs. 1995. Diminished expression of CD40 ligand by activated neonatal T cells. J. Clin. Invest. 95:66-75.

51. Vassilopoulos, D., B. Kovacs, and G.C. Tsokos. 1995. TCR/CD3 complex-mediated signal transduction pathway in $\mathrm{T}$ cells and $\mathrm{T}$ cell lines from patients with systemic lupus erythematosus. J. Immunol. 155:2269-2281.

52. Kammer, G.M., I. Khan, and C. Malemud. 1994. Deficient type I pro- tein kinase A isozyme activity in systemic lupus erythematosus T lymphocytes. J. Clin. Invest. 94:422-430.

53. Maggi, E., M.G. Giudizi, R. Biagiotti, F. Annunziato, R. Manetti, M.-P. Piccinni, P. Parronchi, S. Sampognaro, L. Giannarini, G. Zuccati, and S. Romagnani. 1994. Th2-like CD8+ T cells showing B cell helper function and reduced cytolytic activity in human immunodeficiency virus type 1 infection. $J$. Exp. Med. 180:489-495.

54. Buhlmann, J.E., T.M. Foy, A. Aruffo, K.M. Crassi, J.A. Ledbetter, W.R. Green, J.C. Xu, L.D. Schultz, D. Roopesian, R. A. Flavell, et al. 1995. In the absence of a CD40 signal B cells are tolerogenic. Immunity. 2:645-653.

55. Tsitsikov, E.N., N. Ramesh, and R.S. Geha. 1994. Structure of the CD40 ligand gene. Mol. Immunol. 31:895-900.

56. Facchetti, F., C. Appiani, L. Salvi, J. Levy, and L.D. Notarangelo. 1995. Immunohistologic analysis of ineffective CD40-CD40 Ligand interaction in lymphoid tissues from patients with X-linked immunodeficiency with hyperIgM. Abortive germinal center cell reaction and severe depletion of follicular dendritic cells. J. Immunol. 154:6624-6633.

57. Ware, C.F., P.D Crowe, T.L. Vanarsdale, M.H Grayson, R. Jerzy, C.A. Smith, and R.G. Goodwin. 1991. Tumor necrosis factor (TNF) receptor family expression in T lymphocytes. Differential regulation of the type I TNF receptor during activation of resting and effector T cells. J. Immunol. 147:42294238 .

58. Ranheim, E.A., and T.J. Kipps. 1993. Activated T cells induce expression of B7/BB1 on normal or leukemic B cells through a CD40-dependent signal. J. Exp. Med. 177:925-935.

59. Kennedy, M.K., K.M. Mohler, K.D. Shanebeck, P.R. Baum, K.S. Picha C.A. Ottene-Evans, C.A. Janeway, and K.H. Grabstein. 1994. Induction of B cell costimulatory function by recombinant murine CD40 ligand. Eur. J. Immunol. 24:116-123.

60. Singh, R.R., V. Kumar, F.M. Ebling, S. Southwood, A. Sette, E.E. Sercarz, and B.H. Hahn. 1995. T cell determinants from autoantibodies to DNA can upregulate autoimmunity in murine SLE. J. Exp. Med. 181:2017-2027.

61. Sercarz, E.E., and S.K. Datta. 1994. Mechanisms of autoimmunization: perspective from the mid-90s. Curr. Opin. Immunol. 6:875-881.

62. Gleichmann, E., E.H. van Elven, and J.P.W. van der Veen. 1982. A systemic lupus erythematosus (SLE) like disease in mice induced by abnormal T-B cell cooperation. Preferential formation of autoantibodies characteristic of SLE. Eur. J. Immunol. 12:152-159.

63. James, J.A., T. Gross, R.H. Scofield, and J.B. Harley. 1995. Immunoglobulin epitope spreading and autoimmune disease after peptide immunization: Sm B/B'-derived PPPGMRPP and PPPGIRGP induce spliceosome autoimmunity. J. Exp. Med. 181:453-461.

64. Desai, D.D., M.R. Krishnan, J.T. Swindle, and T.N. Marion. 1993. Antigen-specific induction of antibodies against native mammalian DNA in nonautoimmune mice. J. Immunol. 151:1614-1626.

65. Moens, U., O.-M. Seterenes, A.W. Hey, Y. Silsand, T. Traavik, B. Johansen, and O.P. Rekvig. 1995. In vivo expression of a single viral DNA-binding protein generates systemic lupus erythematosus-related autoimmunity to double-stranded DNA and histones. Proc. Natl. Acad. Sci. USA. 92:1239312397.

66. Schattner, E.J., K.B. Elkon, D.-H. Yoo, J. Tumang, P.H. Krammer, M.K. Crow, and S.H. Friedman. 1995. CD40 ligation induces Apo-1/Fas expression on human B lymphocytes and facilitates apoptosis through the Apo-1/Fas pathway. J. Exp. Med. 182:1557-1566.

67. Finck, B.K., P.S. Linsley, and D. Wofsy. 1994. Treatment of murine lupus with CTLA4Ig. Science (Wash. DC). 265:1225-1227.

68. Klaus, S.J., L.M. Pinchuk, H.D. Ochs, C.-L. Law, W.C. Fanslow, R.J Armitage, and E.A. Clark. 1994. Costimulation through CD28 enhances T celldependent B cell activation via CD40-CD40L interaction. J. Immunol. 152: 5643-5652.

69. Datta, S.K., C. Mohan, and A. Desai-Mehta. 1995. Mechanisms of the pathogenic autoimmune response in lupus: Prospects for specific immunotherapy. Immunol. Res. 14:132-147. 